Meta

Journal des traducteurs

Translators' Journal

\title{
Madeleine SERGENT and Kay WILKINS (1985) : A Translation Textbook, New York, University Press of America, xii + 127 p.
}

\section{Blake T. Hanna}

Volume 35, numéro 2, juin 1990

URI : https://id.erudit.org/iderudit/003004ar

DOI : https://doi.org/10.7202/003004ar

Aller au sommaire du numéro

\section{Éditeur(s)}

Les Presses de l'Université de Montréal

\section{ISSN}

0026-0452 (imprimé)

1492-1421 (numérique)

Découvrir la revue

Citer ce compte rendu

Hanna, B. T. (1990). Compte rendu de [Madeleine SERGENT and Kay WILKINS (1985) : A Translation Textbook, New York, University Press of America, xii + 127 p.] Meta, 35(2), 427-429. https://doi.org/10.7202/003004ar d'utilisation que vous pouvez consulter en ligne.

https://apropos.erudit.org/fr/usagers/politique-dutilisation/ 
Madeleine SERGENT and Kay WILKINS (1985): A Translation Textbook, New York, University Press of America, xii +127 p.

"Learning a language by means of translation exercises is a time-honored method" (p. 1), declare the authors of this textbook intended for second- or third-year French majors in American college and university B.A. programmes. While pointing out that audio-visual means of instruction have made translation unpopular as an initiation to foreign language study, they underscore its validity in increasing the abilities of students who already possess a strong background in a foreign language. By providing such students with a wide variety of authentic material for translation into and out of French, Sergent and Wilkins aim to develop a sensitivity in students to differences in style, encourage wider reading, expand their vocabularies, develop translating speed and deepen their appreciation of a foreign culture. They do so by presenting the student with a 
collection of texts divided into six chapters dealing with journalism, politics, administration, social sciences, economics and science and technology.

Translation theory and technique are dealt with empirically: "It is the belief of the authors of this textbook that true understanding of the differences between the languages can only arise through practical application rather than theoretical study" (p. 3). They refer the reader to Jean-Paul Vinay and Jean Darbelnet's Stylistique comparée du français et de l'anglais ${ }^{\prime}$ for an analysis of the theoretical background to their textbook and the method it follows, advising the student to read and understand each text, organize it into sense units, become familiar with the necessary vocabulary, verify terms in a unilingual dictionary and take cultural differences into consideration. In connection with the latter points, they warn students that they are unlikely to find either current slang or such terms as "gang-rape" or "sexual harassment" in any dictionary that is available to them (p. 5). These and problems posed by such cultural allusions as maitre des requêtes, "House Joint Resolution," or Pieds-noirs will likely require research in current periodicals, encyclopedias and specialized publications (p. 6).

Following a discussion of transpositions, prepositions, abstract versus concrete language, the use of tenses, adjectives and inversions, and the tendency in English to accumulate nouns in sense units such as "oil price rise" or "government procurement strategy" (p. 9), they present a detailed discussion of two of their texts as a sample of how to use the book, before turning the reader loose on the corpus itself.

Each chapter of the corpus includes five texts in French to be translated into English and five texts in English to be translated into French. Each text is about 300 words in length. Drawn from various English, French, American and Canadian sources, these texts are intended to familiarize the student with such matters as the difference between British and American English, formal vs. informal reporting styles, the evolution of French politics from De Gaulle to Mitterand, tensions between Quebec and the rest of Canada, the unique character of administrative language, social issues in contemporary France, and supply-side economics in the U.S. and U.K., as well as recent French scientific and technical accomplishments, together with the specialized vocabulary necessary to deal with them in English.

Examples of these texts are "August Traffic Jams in France" from The Guardian (August 1, 1980); "Les ministres communistes du gouvernement Mitterand" from l'Express (14 août 1981); René Lévesque's "Le projet québécois" from l'Action nationale (1978), p. 343; "The parti communiste français" from J.R. Frears' Political Parties and Elections in the French Republic (1977), pp. 151-153; Procès-verbal d'une séance du Conseil supérieur de l'éducation nationale (lundi 10 mars 1980); U.S. president Jimmy Carter's proclamation of January 30, 1979 concerning a National Inventors' Day; an excerpt from "Les rapatriés d" Algérie en France" published in Notes et Études documentaires (29 mars 1976), p. 7; a story published in The Observer on June 29, 1980 telling how President Valéry Giscard d'Estaing was trying to get the French to stop drinking so much; excerpts from a Financial Post article of February 10, 1979 concerning the Prime Minister Raymond Barre's visit to Canada; "Débat sur les surrégénérateurs..." from l' Express (27 septembre 1980) and a New York Times article dated April 20, 1982 concerning a birth control pill you only have to take for four days a month.

Most of these texts are dated 1979,1980 or 1981 , but one or two are as recent as 1982 and a few date back as far as 1940. Undoubtedly authentic in origin and of unquestioned variety and interest, they betray the inherent danger in attempting to publish a textbook of this sort: by the time it gets into print, it is largely out of date. Though the texts are well chosen, there was a three-year time lag between the most recent of them and the book's publication. One year after publication, some $35 \%$ of them are already outdated. 
The remainder are either timely, timeless, or of historical interest. This problem appears to be a fundamental one that can only be remedied by accelerating textual manipulations prior to publishing and by an annual revision the popularity of the text may not render economically feasible.

The corpus is followed by a twelve-page vocabulary and an appendix of recommended dictionaries which appears to be updated to 1983 or 1984 . META readers will be gratified to learn by consulting this material that "gang-rape" may be translated by viol collectif (p. 120), while maître des requêtes is described as a magistrat qui fait office de rapporteur au Conseil d'État (p. 41). The other expressions cited above are left up to the initiative of the students.

Thoughtfully conceived, carefully edited, the text would appear to be a useful one for the targeted level of students. It is, however, quickly outdated and is not intended for the training of professional translators.

BLAKE T. HANNA

\section{Note}

1. Paris, Didier et Montréal, Beauchemin, 1971. 